\title{
Fokus på kvalitetsforbedring, nå også i forskning
}

\author{
Kvalitetsforbedring av helsetjenesten har i mange år vært et forsømt \\ felt i akademia. De siste årene har vist en oppløftende utvikling, og det \\ er nå på tide å få etablert et akademisk miljø som har forbedrings- \\ prosesser som hovedfokus.
}

Flere miljøer innenfor helsetjenesten har nå fått øynene opp for det potensial som ligger $i$ en mer systematisk tilnærming til forbedringsprosesser. Gjennom kartlegging, iverksetting av forbedringer og monitorering av endring ved bruk av statistisk prosesskontroll søker man å forbedre de tilgjengelige metoder for pasientbehandling. Denne tenkningen har bl.a. ligget til grunn for det som kalles «gjennombruddsmetoden», som Legeforeningen har anvendt i flere nasjonale forbedringsprosjekter siden 1999 (1). Fordi metodologien har falt utenfor de tradisjonelle vitenskapelige publiseringsnormer, har det vært beskjeden publisering tekst (Lungeavdelingen, Haukeland universitetssykehus), som forfatterne påvirker ved ulike endringer, og resultatet dokumenteres ved målinger som er egnet for denne type endringsarbeid (målbar forbedring av prestasjon). Avhandlingen bør leses av alle som er på jakt etter nye metoder for å kunne drive forbedring av pasientbehandling i ulike avdelinger og miljøer.

I Nasjonal strategi for kvalitetsforbedring av Sosial- og helsetjenesten 2005-2015 (8), som er en del av Nasjonal helseplan, er det en uttalt strategi at forbedringskunnskap skal inn i alle helseutdanninger. Det er en veritabel utfordring, og vi har ikke kommet

\section{«I Norge mangler vi et akademisk miljø med hovedformål å arbeide med system- og prosessforbedring av klinisk virksomhet.»}

av resultatene. Et unntak er Guttorm Brattebø og mearbeideres publikasjon fra gjennombruddsprosjektet $\mathrm{i}$ intensivmedisin (2). Men i løpet av de to siste par år har vi hatt en omfattende internasjonal prosess som har ledet opp til et sett med publiseringskriterier kalt SQUIRE (Standards for QUality Improvement Reporting Excellence (3)) som forhåpentlig vil gjøre systematisk forbedringsarbeid lettere tigjengelig og gi dem som driver slikt arbeid på en ryddig måte, bedre uttelling i form av vitenskapelige meritter.

Høsten 2008 disputerte Christian von Plessen ved Universitetet i Bergen. Avhandlingen er basert på tre artikler (4-6). En av artiklene viser hvordan moderne tenkning knyttet til forbedringskunnskap (improvement science), kan forbedre de prosesser som er med på å bestemme kvaliteten på pasientbehandlingen (5). Så vidt meg bekjent, er det den første medisinske avhandlingen i Norge der ett av arbeidene er publisert etter SQUIRE-kriteriene. Avhandlingen er et eksempel på bruk av et konsept beskrevet av Batalden \& Davidoff (7). Medisinsk behandling er forankret i best tilgjengelig kunnskap (generalisert vitenskapelig evidens) som gis i en spesifikk kon- særlig langt i løpet av de drøyt tre årene som er gått siden strategien ble publisert. Her har alle helsefaglige utdanninger en viktig oppgave. Kanskje blir det lettere for de medisinske fakultetene å ta skikkelig tak i dette nå som publisering av gode kvalitetsprosjekter er en reell mulighet. Men fortsatt vil det være pasientene som vil profittere mest på en skikkelig satsing på styrking av forbedringskunnskapen i alle helsepersonellutdanninger. Og det burde faktisk være grunn god nok også for de medisinske fakultetene til å styrke sin satsing på dette feltet, slik Oslo-fakultet forsøker gjennom sitt KLoK-fag (integrering av kunnskapshåndtering, ledelse og kvalitetsforbedring).

Vi trenger miljøer, mange miljøer, som har kompetanse til å arbeide i skjæringsfeltet mellom tradisjonell medisinsk vitenskap og det mer prosessorienterte forbedringsarbeidet som er helt nødvendig for god kvalitet i pasientbehandlingen. Det siste politiske utspillet fra helseministeren, der søkelyset settes på samhandling, er viktig. Men det må ikke behandles isolert fra det å få system- og prosesstenkningen inn i all klinisk virksomhet, i mikrosystemene, som er «enhetene» i samhandlingskjedene (9). I Norge mangler vi et akademisk miljø med hovedformål å arbeide med system- og prosessforbedring av klinisk virksomhet. Kanskje det er ved fakultetet i Bergen at det første instituttet av en slik type skal komme? I Bergen har de også allmennmedisinske miljøer som ligger langt fremme i moderne forbedringsarbeid (10).

\section{Hans Asbjørn Holm}

asbjholm@online.no

Grimelundsveien 5C

0775 Oslo

Oppgitte interessekonflikter: Forfatteren arbeider som seniorrådgiver i Helsedirektoratet, Avdeling for kvalitet og prioritering.

\section{Litteratur}

1. Den norske legeforening. Gjennombruddsprosjek ter. www.legeforeningen.no/id/79985 (16.4.2009)

2. Bratteb $\varnothing \mathrm{G}$, Hofoss $D$, Flaatten $\mathrm{H}$ et al. Effect of a scoring system and protocol for sedation on duration of patients' need for ventilator support in a surgical intensive care unit. BMJ 2002; 324: $1386-9$.

3. Davidoff F, Batalden P, Stevens D et al. Publication guidelines for improvement studies in health care: evolution of the SQUIRE Project; SQUIRE Development Group. Ann Intern Med 2008; 149: 670-6.

4. von Plessen C, Bergman B, Andresen 0 et al. Palliative chemotherapy beyond three courses conveys no survival or consistent quality-of-life benefit in advanced non-small-cell lung cancer. $\mathrm{Br} \mathrm{J}$ Cancer 2006; 95: 966-73.

5. von Plessen C, Aslaksen A. Improving the quality of palliative care for ambulatory patients with lung cancer. BMJ 2005; 330: 1309-13.

6. von Plessen C, Strand T-E, Wentzel-Larsen T et al. Effectiveness of third generation chemotherapy on the survival of patients with advanced non-small cell lung cancer in Norway - a national study. Thorax 2008; 63: 866-71.

7. Batalden PB, Davidoff F. What is «quality improvement» and how can it transform healthcare? Qual Saf Health Care 2007: 16: 2-3.

8. ....og bedre skal det bli! Nasjonal strategi for kvalitetsforbedring i sosial og helsetjenesten (2005-2015). Oslo: Sosial- og helsedirektoratet, 2005

9. Nelson EC, Batalden PB, Godfrey MM. Quality by design: a microsystems approach. San Francisco, CA: Jossey-Bass, 2007.

10. Malterud K. Forebygging av faglige feil på allmennlegekontoret. Tidsskr Nor Lægeforen 2007; 127: $2239-41$.

Manuskriptet ble mottatt 15.1. 2009 og godkjent 16.4. 2009. Medisinsk redaktør Anne Kveim Lie. 